This item was submitted to Loughborough's Research Repository by the author.

Items in Figshare are protected by copyright, with all rights reserved, unless otherwise indicated.

\title{
The Bloomsbury Handbook of Electronic Literature. Edited by Joseph Tabbi
}

\section{PLEASE CITE THE PUBLISHED VERSION}

https://doi.org/10.1093/english/efz010

\section{PUBLISHER}

Oxford University Press on behalf of the English Association. () The Author

\section{VERSION}

AM (Accepted Manuscript)

\section{PUBLISHER STATEMENT}

This is a pre-copyedited, author-produced version of an article accepted for publication in English: Journal of the English Association following peer review. The version of record HENRICKSON, L., 2019. The Bloomsbury Handbook of Electronic Literature. Edited by Joseph Tabbi. English: Journal of the English Association, 68 (260), pp.95-98 is available online at: https://doi.org/10.1093/english/efz010

\section{LICENCE}

CC BY-NC-ND 4.0

\section{REPOSITORY RECORD}

Henrickson, Leah. 2019. "The Bloomsbury Handbook of Electronic Literature. Edited by Joseph Tabbi". Loughborough University. https://hdl.handle.net/2134/37142. 
The Bloomsbury Handbook of Electronic Literature. Edited by Joseph Tabbi. London: Bloomsbury, 20187. ISBN: 9781474230254.450 pages. $£ 90.00, \mathrm{hb}$.

Digital technologies inform many aspects of modern reading and writing experiences: word processing software highlights spelling errors with red squiggly lines; Grammarly (www.grammarly.com) advertisements abound, promising improved style; online dictionaries and thesauri make referencing quick and easy. Yet there are also those interactions with the digital that are more conspicuous. This is the world of electronic literature (e-lit): where the digital not only supports the writing process, but plays an integral part in a text's development and reception.

According to the synopsis on its back cover, The Bloomsbury Handbook of Electronic Literature is 'the first authoritative reference handbook to the field', and 'is an essential resource for scholars of contemporary culture in the digital era.' This book, comprising 23 chapters by e-lit scholars and practitioners, as well as an annotated bibliography of relevant resources, explores the vastness of a still-emerging field through four purposely vague sections: (1) Ends, Beginnings; (2) Poetics, Polemics; (3) Materialities, Ontologies; and (4) Economies, Precarities. Together, the chapters provide a wide-ranging introduction to the state of the field.

Yet The Bloomsbury Handbook is, in actuality, not so much a handbook of e-lit as it is a collection of profound investigations into broad concepts such as posthumanism, hypertextuality, digital aesthetics, and - to use the name of Florian Cramer's contribution - 'post-digital writing'. Indeed, the book identifies many social and literary implications of e-lit, but never actually explains what is meant by e-lit. The responsibility for defining the term appears to have been left to the contributors, most of whom dive immediately into analyses of their topics rather than assume the burden of context. It is not until chapter eighteen - 'Of Presence and Electronic Literature' - that the first explicit definition of e-lit appears, with Luciana Gattass only briefly summarising these works as 'digitally born literary objects meant to be experienced within networked and programmable media environments' (p. 323). Given that 'handbook' implies a basic guide, the obscurity of such a key term 
- however difficult it may be to define - in The Bloomsbury Handbook is especially noticeable. Those looking for works that serve as more accessible introductions to e-lit may benefit from returning to N. Katherine Hayle's 2008 Electronic Literature: New Horizons for the Literary, which provides the first systematic survey of the field, or Scott Rettberg's 2019 Electronic Literature, which provides an updated survey. ${ }^{1}$

Once one accepts that The Bloomsbury Handbook is a report on the state of the field rather than an introduction to e-lit, though, the book's value is clear. As a resource for those already at least somewhat familiar with the world of e-lit, the chapters in The Bloomsbury Handbook all offer nuanced and substantive discussions, driven by argumentative positions, that present shrewd insight into relevant issues within the field. In particular, all of the chapters emphasise the underlying political nature of e-lit works, and these works' fundamental subversion of the hegemonic social and literature structures that constitute 'conventional' literature. More specifically, most of the chapters share an underlying theme: the power of e-lit to confront linguistic and capitalist power structures. Each chapter may be read in isolation, but when read together the chapters illuminate the many social and literary effects of e-lit as a practice, as well as that practice's resultant output. Whether or not the e-lit works cited as examples will stand the test of time (and, for many, the diligent payment of website and server costs), the topics addressed by the The Bloomsbury Handbook's contributors will continue to be relevant so long as we continue our journey into an increasingly digital age. Given the cross-disciplinary applicability of this collection (literary studies, digital humanities, computer science, and sociology, to list just a few), librarians would be wise to include it in any e-lit collection. Likewise, instructors writing e-lit syllabi for undergraduate or graduate modules may find certain chapters appropriate for supplementary reading.

\footnotetext{
${ }^{1}$ N. Katherine Hayles, Electronic Literature: New Horizons for the Literary (Notre Dame: University of Notre Dame Press, 2008); Scott Rettberg, Electronic Literature (Cambridge: Polity, 2019).
} 
Further, the annotated bibliography at the end of the book reviews other articles, books, and e-lit works that would enhance any e-lit reading list. As editor Joseph Tabbi explains in the annotated bibliography's introduction, '[w] hat we intend here is to convey a sense of what early career scholars are currently reading; what those selections say about where the field has been, and what these researchers are now saying about where the field might, or might not be heading' (p. 421). Entries have all been written by graduate students, save for one by Tabbi himself. Although many of the entries assume at least basic knowledge of the field, this section of the book comes the closest to offering the contextual discussion of e-lit that is missing from the Handbook, and may therefore be of particular value to less familiar with the field.

As a final aside, it is worth noting the apparent irony of this book's publication in codex form. Yet as Mario Aquilina observes in 'Electronic Literature and the Poetics of Contiguity', emphasising continuities over radical breaks induced by new electronic media 'urges us to see the value of digital works that may, from a certain conservative perspective about literature, be dismissed as nonliterary or not worthy of literary analysis or evaluation' (p. 206). The book's form itself is a statement. Despite e-lit's subversion of conventional literature, it is a field deeply rooted in the traditional. And, as all of The Bloomsbury Handbook's chapters stress, e-lit is a performance, an event, an experience. Using the familiar form of the codex as its stage, the Handbook guides potentially sceptical readers through a vast and lively scene.

The Bloomsbury Handbook of Electronic Literature is a worthy addition to the e-lit scholar's bookshelf. Contrary to what its name may connote, however, it is not an introduction to world of elit, but a state of the field. Rather than a handbook, it is a review of the more complex social and literary issues posed and faced by e-lit. As we venture deeper into our digital age, scrutiny of such issues will only be of greater importance and value. 